\title{
Under the Cloak of Whiteness: A Circuit of Culture Analysis of Opportunity Hoarding and Colour-blind Racism Inside US Advertising Internship Programs
}

\author{
Christopher Boulton
}

University of Tampa, Tampa, USA, cboulton@ut.edu

\begin{abstract}
Drawing on qualitative fieldwork at three large agencies, this article adapts Richard Johnson's "circuit of culture" (1986) as a framework to examine both the material practices that help reproduce an overwhelmingly white labour force within US advertising agencies and the ideological screens that conceal them from scrutiny, critique, and reform. I argue that efforts to diversify advertising through internship-based affirmative action programs are ultimately undermined and overwhelmed by the more widespread systems of white privilege whereby agency executives and powerful clients bypass the application process and directly place personal friends and relatives into highly sought after internship slots. Furthermore, I contend that such material practices of class preference are masked, and thereby enabled, by ideological screens of colour-blind meritocracy. I argue that colour-blindness leads to meritocracy in theory, but race discrimination in practice, and conclude with a discussion of some possible implications for communication theory in general and critical media industry studies in particular.
\end{abstract}

Keywords: internships, advertising, race, class, labour, ideology, meritocracy, white privilege, affirmative action

Acknowledgement: This research project was funded by The University of Tampa Dana Foundation Grant.

To date, most of the critical work on internships has hinged on the exploitation of labour and the reproduction of class hierarchies, whether it be already indebted college graduates willing to forgo payment in order to get a foot-in-the-door of a desirable industry or those privileged enough to trade economic capital for cultural capital in pursuit of the same (Hesmondhalgh and Baker 2011; Neff, Wissinger, and Zukin 2005; Perlin 2011; Stahl 2012). Such speculative, and indeed risky, investments of time, energy, and value creation in exchange for potential, and often improbable, future pay-offs have been theorized as "venture labor" (Neff 2012), "hope labor" (Keuhn and Corrigan 2013), and even "living in the subjunctive" (Streeter 2014). As Alexandre Frenette $(2013,371-72)$ argues, internships are the most liminal of work spaces as they tend to couple provisional periods of precarious employment (often with no pay and few rights) with the prospect of self-actualization and relative autonomy through future job security and career advancement; many a master has promised his slave deferred rewards in heaven. And yet, while some have proposed eliminating unpaid internships through activism, government regulation, or class-action lawsuits, Frenette (391) warns that such an ostensibly righteous cause could eradicate many internship programs, increase the selectivity of those that remain, and foreclose one of the few points of entry for underrepresented and not-so-well-connected populations. In what follows, I suggest that internships can be problematic not just in terms of class but also race. To do so, I examine how internships in major US advertising agencies, despite being paid and occasionally designated to meet diversity objectives, nevertheless help reproduce race inequalities under the cloak of whiteness.

In May of 2009, Dan Wieden (2009), CEO of Nike's lead advertising agency, shocked a national gathering of the American Association of Advertising Agencies (4A's) - the largest advertising trade organization in the U.S-by criticizing his own agency's hiring of white people to sell black culture as "fucked up." Citing statistics on minority underrepresentation 
across the advertising industry as a whole,${ }^{1}$ he chastised his audience: "I thought, maybe, just maybe it might be more inspirational to hear from someone as screwed up as you are. And you are screwed up, aren't you? I mean look at this room: how many black faces do you see here?" Wieden's focus on African-Americans is understandable. The National Association for the Advancement of Colored People (NAACP) had just released the newest in a series of reports denouncing the advertising industry's unique and persistent inability to hire and promote blacks (Bendick and Egan 2009). Among other indicators of discrimination, the report cited a black-white employment gap thirty-eight percent larger than the labour market in general-a divergence that has doubled over the past thirty years-and a system of "glass ceilings" and "glass walls," relegating blacks to less prestigious support functions (ibid. 33). After reading the report, Nancy Hill, President-CEO of the 4A's-pled no contest: "The numbers speak for themselves" (Hill quoted in Parekh 2009).

Race inequality inside advertising is a familiar problem with a long history and a disturbing present (Chambers 2008; Turow 1997). In the 1960s and 1970s, frustrated by explicit race discrimination at large white-owned agencies, a few black advertising practitioners opened their own shops and rebranded black skin colour as a sign of unique expertise and cultural insight into the lives of black consumers. As Jason Chambers (2008) argues, this positioning of black identity as an entrepreneurial "on-ramp," though successful at first, soon turned to detour as it unwittingly provided white advertisers and agencies with a rationale for not employing blacks to market to white consumers (aka: the "general market") and, instead, resegregated the industry by relegating black employees to black accounts where they would market to their "own" people with much smaller budgets (Chambers 2008, 255). Careers stall and people leave. On-ramp turns to detour; detour turns to exit. As such, Wieden's public confession was an embarrassing, if not altogether surprising, disclosure of a well-known secret hidden in plain sight. For instance, in 2010, the NAACP found that all 52 of the major agency spots aired during the 2010 Super Bowl had white creative directors and warned that a lawsuit was imminent, prompting Advertising Age to predict that the industry's "dismally poor performance in diversity" would "hit a crescendo" in 2011 as "class action attorneys join the fray and push for reform" (Lapchick et al. 2010; Dolliver 2010; Wood 2010). By the following spring, the New York City Commission on Human Rights had concluded that advertising's aversion to hiring minorities seemed so entrenched that "they have to do something to change the entire culture" (Bush 2011). In sum, there is a clear consensus among industry insiders, the NAACP, the trade press, and governmental regulators: advertising has a serious race problem-particularly when it comes to the under-hiring and under-utilization of black employees. Less clear is why and how.

This article draws on qualitative fieldwork at three large agencies to take a closer look at both the material practices that help reproduce an overwhelmingly white labour force within US advertising agencies and the ideological screens that conceal these practices from scrutiny, critique, and reform. I argue that the industry's efforts to diversify its workforce through internship-based affirmative action programs are ultimately undermined and overwhelmed by the more widespread systems of white privilege whereby agency executives and powerful clients bypass the application process and directly place personal friends and relatives-aka "must-hires"-into highly sought after internship slots. Furthermore, I contend that such material practices are masked, and thereby enabled, by ideological screens of colour-blind meritocracy. In short, I argue that colour-blindness leads to meritocracy in theory, but discrimination in practice, and conclude with a discussion of some possible

\footnotetext{
${ }^{1}$ According to Wieden (2009), Latinos, blacks, and Asians make up 14.5 percent, 13 percent, and 4.25 percent of the US population and only 8 percent, 5 percent, and 3 percent of advertising industry employees respectively. So, while all three groups are underrepresented, Asians are faring best, by far, with employment rates around 70 percent of their population percentage while Latinos are 55 percent, and blacks trail a distant third at 38 percent. At the managerial level, the numbers are even worse. Of the 87,000 advertising and promotions managers in the United States, 5.6 percent are Latino, 1.6 percent Asian, and 1.6 percent black (Bureau of Labor Statistics 2011, 20).
} 
implications for communication theory in general and critical media industry studies in particular.

\section{Literature Review: Beyond Representation}

The current study responds to David Hesmondhalgh and Anamik Saha's (2013) call to complement the abundance of research on media content and audiences with a more systematic cultural industries approach to race and ethnicity that is at once theoretical and empirical. More specifically, I seek to go beyond demonstrating inequalities within advertising and move towards explaining why the current situation came about and how it still manages to persist despite a myriad of well-meaning efforts to correct it. Such questions matter precisely because the cultural industries' products communicate "ideas, knowledge, values and beliefs," and thus have the capacity to "exert considerable influence on societies and peoples" (187). Or, as Lee Edwards (2013) puts it, this sector's often racialized conditions of production not only affect the labourers themselves, but also, in turn, inflect the symbolic messages those labourers then work to circulate or suppress. But while the racial and ethnic identities of workers can help shape the form and content of cultural products, the "pipeline" diversity tactic of bringing more employees of colour into media organizations has not always improved the representation of racial minorities in media texts. Whether it be PR practitioners (Edwards, 2013), Latino/a advertising professionals (Dávila 2001), BBC television producers (Cottle, 1998), or Asian filmmakers (Saha 2012), researchers have repeatedly found that creative workers of colour must continue to negotiate, and often pander to, white racial assumptions in order to advance their careers. Such hedging can inhibit creative work by incentivizing conservative and risk-averse strategies such as peddling well-trodden racial and ethnic tropes that can more easily sell through white conduits of approval. Thus, as Devon Carbado and Mitu Gulati (2003) argue, even though "the illegitimacy of an all-white workforce imposes a diversity constraint" on employers, they nevertheless homogenize the hiring process by continuing to favour job candidates of colour that demonstrate their willingness and ability to assimilate, and thereby maintain, the efficiency of a monocultural workplace (1762). In this way, savvy nonwhite workers perform their raced selves through daily strategic identity transactions intended to placate white colleagues (also see Boulton 2014).

And while the preceding body of empirical work has demonstrated how people of colour must often negotiate white expectations in the workplace, critical race theory (CRT) has theorized how whites, in turn, enjoy a race-less form of invisibility-an empty category or the ground of normality against which the figures of more "raced" peoples are measured (Dyer 1997; Shome 2000). Put another way, if whiteness is the canvas, neutral and unassuming, then people of colour are the pigment, different and exotic, such that, in advertising agency settings, whiteness blends in and colour stands out. So, while race, as a category, may be constructed-has a history and is subject to change-it nevertheless produces concrete effects since whites' claims of colour-blindness are largely irrelevant to the successful reproduction of white privilege. As Eduardo Bonilla-Silva (2010) argues, whites reconcile persistent racial inequalities through "color-blind racism." Unlike Jim Crow racism, which is explicitly based on theories of biological and moral inferiority, colour-blind racism is based in a more "reasonable" philosophy of abstract liberalism that endorses equal opportunity in theory but opposes any substantive regulatory policy response (such as affirmative action). Instead, the colour-blind racist presumes prejudice to be in the past and favours free market correctives such as individual choice and the meritocratic dispersal of rewards as the appropriate means to right the scales. However, despite such "blindness," whites still seem to see, and prefer, their own colour almost all the time, choosing to "live in white neighborhoods, associate primarily with whites, befriend mostly whites, and choose whites as their mates," all the while refusing to "interpret their hypersegregation and isolation from 
minorities (in particular blacks) as a racial outcome" but rather just "the way things are" (Bonilla-Silva 2010, 263).

In another study of unperceived white affiliation, preference, and privilege, Royster (2003) found that whites benefiting from networks effectively excluding black men from blue-collar jobs still felt disadvantaged by affirmative action. Their inability to recognize whiteness blinded them to the racial pattern of the family and friendship ties used for "employment referrals, access, and mobility" and that they occurred within "persistent patterns of segregation-equivalent to an American apartheid" $(179,184)$. Royster goes on to describe this process as a form of "embeddedness" whereby any given job has a pool of qualified candidates, but getting notified and hired depends not only on what you know, but also who you know, and how. To get ahead requires being in the right place in the right time, and whites' life chances in the cultural industries are ever increased by their frequent access to those right places. For instance, Kate Oakley (2011) has found that the cultural labour market in the UK, despite its progressive reputation, engages in social exclusion along ethnic lines through unpaid internships and informal recruitment strategies favouring the white and well-connected. Similarly, John Downing and Charles Husband (2005) describe how film and television workers navigate the precarity of irregular employment by forming informal referral networks that tend to exclude minorities and women such that the mentorship of friends helping friends can quickly lead to cronyism. Carbado and Gulati (2003) praise CRT's institutional analysis of racism as structure rather than individual attitude, but also critique the tendency of such a macrocosmic perspective to miss the "microdynamics of race" as played out in complex and contested ways through social interaction in the workplace. This study takes up the challenge to look closer at the microdynamics of the everyday in advertising internship programs.

Most communication scholars addressing race in advertising have done so on the level of representation, analyzing the ads as texts (Bristor, Lee, and Hunt 1995; Cortese 1999; KernFoxworth 1994; O'Barr 1994). These studies, along with various content analyses, which count minority characters and evaluate casting decisions and depictions in advertising (Gilmore and Jordan 2012; Henderson and Baldasty 2003; Seiter 1990) as well as primetime television (Fall Colors 2003; Monk-Turner, Heiserman, Johnson, Cotton, and Jackson 2010; Signorielli 2009), have demonstrated a clear and consistent bias towards white protagonists and stereotypical portrayals of minorities. And while this literature can quantify how media representations create a cultural environment of inequality and help activists pressure advertisers and networks to cast their commercials and programs in ways that better reflect the diversity of the general population, ${ }^{2}$ even the most critical analysis of race on the level of representation only takes us so far.

Johnson's "circuit of culture" proposes that cultural studies "decenter the text" and analyze communication throughout a continuous circuit divided into moments of 1) production, 2) texts, 3) readings, and 4) lived cultures $(1986,62)$. Since representation on screen can conceal the conditions of production behind the camera, communication research that goes beyond (and indeed behind) the text can provide new insights into the everyday life of labour in the creative industries. ${ }^{3}$ As David Hesmondhalgh $(2007,37)$ puts it, cultural studies is most

\footnotetext{
${ }^{2}$ For instance, in the fall of 1999 , the NAACP protested the new slate of network television programming as a "'virtual whitewash"' (quoted in Gross 2001).

3 Though the production side of Johnson's circuit remains generally underdeveloped in communication, there are several agency-based ethnographies conducted by sociologists including William Mazzarella (2003) in India, Daniel Miller (1997) in Trinidad, Brian Moeran (1996) in Japan, and Sean Nixon (2003) in Britain. The paucity of work in the United States is curious, given that two of the four biggest holding companies (Interpublic and Omnicom) are headquartered in New York City. Though not ethnographies per se, there have also been several interview-based examinations of contemporary advertising practices in the United States: the segmentation and consolidation of Latino/a identity (Dávila 2001), the absence of female creative directors (Mallia, 2009), the development of gay marketing (Sender 2004), and the commodification of "true" blackness (Watts and Orbe 2002).
} 
useful when it asks "whose voices are heard within a culture and whose voices are marginalized" in order to better "assess the degree to which cultural production is organized in a socially just manner." This work is particularly important since, as Rosalind Gill (2014) reminds us, this sector's structural inequalities are often masked, and thus rendered "unspeakable" and more easily reproduced, by ideologies of individualism and egalitarianism. In that spirit, this project focuses on the production side of Johnson's circuit in order to interrogate the black-white labour gap within inside the US advertising industry. ${ }^{4}$ In doing so, it contributes to a rich sociological literature documenting and theorizing the reproduction of racial hierarchies within workplace settings largely through informal hiring practices based on existing social networks (Acker 2006; Branch 2011; Das Gupta 1996; McGuire 2002; Vallas 2003). Others have drawn similar conclusions through researching specific communication industries including telephony (Green 2001), journalism (Becker, Lauf, and Lowrey 1999; Drew 2011), and public relations (Logan 2011).

In what follows, I adapt Johnson's (1986) circuit model as an analytical framework for assessing the advertising sector from the inside. ${ }^{5}$ Rather than follow an ad from agency conception out the door to audience reception, I examine moments along the circuit in the manufacture and maintenance of labour inequality along racial lines. First I recount the production of white privilege through opportunity hoarding. Next I conduct a close reading of two competing texts-diversity as "smart" and diversity as "right"-that, albeit counterintuitively, help to perpetuate this inequality. Third, I consider how ideological readings through the lens of colour-blind racism and meritocracy make it difficult for even the most well-meaning of whites to behold how the structures and habits of class privilege flourish in agency settings under the cloak of whiteness. Finally, I conclude with a reflection on what the circuit of culture approach to race in the cultural industries might reveal about the theory and ethics of future work in this area.

\section{Methods}

I accessed the advertising industry through the 4A's Multicultural Advertising Intern Program (MAIP) - an effort founded in 1973, which has since "helped jumpstart the careers of more than 2,000 African-American, Asian-American, Latino-American, Native-American, multiracial and multiethnic aspiring advertising professionals" (4A's 2010). MAIP recruits and screens around 140 students of colour every year from all over the country, then places them in agencies willing to pay 70 percent of their travel and rent (in addition to the standard stipend which ranged from $200-\$ 500$ dollars per week) during their own internal summer internship programs. I entered the field through MAIP for three reasons. First, it ensured that my analysis would include a wide variety of perspectives from people of colour. Second, since the MAIP interns were placed in nineteen different agencies, their participation in my study greatly expanded the reach of my data. ${ }^{6}$ Finally, MAIP's centralized housing enabled a convenient and comfortable gathering place for focus group discussions. After negotiating MAIP's full cooperation, I spent the summer of 2010 in New York City, attending the MAIP

\footnotetext{
${ }^{4}$ Elsewhere, I have analyzed how intersections of race and gender inequalities inside advertising tend to reproduce white male leadership through informal hiring practices based on personal referrals and team-based chemistry/fit (Boulton 2013). For more on gendered labour in advertising, see Broyles and Grow (2008) and Michelle Gregory (2009).

${ }^{5}$ Though space does not permit me to include an analysis of Johnson's "lived cultures" in this work, I have taken a closer look at the contradictions of black identity inside advertising elsewhere (Boulton forthcoming).

${ }^{6} 61$ interns participated in at least one of my focus groups. Together, they represented 19 different advertising agencies in New York City: DDB, Deutsch, Draftfcb, Euro RSCG, G2, Gotham, Grey Group, Horizon Media, Kaplan Thaler Group, Kirshenbaum Bond Senecal + Partners, McCann Erickson, McGarryBowen, MEC, Mediacom, Merkley + Partners, Ogilvy \& Mather, PHD Worldwide, Publicis, TBWAIChiatlDay. As a whole, my sample of 61 interns was largely female (72 percent) and comprised almost entirely of undergraduates (college juniors and seniors). Thirty-six were MAIP interns (59 percent) and 25 were white interns (41 percent). Overall, this study includes a total of 109 unique informants that participated in 21 focus groups, filled out 149 surveys, and granted 30 interviews. I also recorded interviews and took ethnographic field notes while on-site at my host agencies.
} 
orientation, weekly evening seminars, social events, and graduation ceremonies. I also secured access to three of MAIP's host agencies, ${ }^{7}$ visiting each once a week for the duration of their eight to 10 week internship programs. In addition to ethnographic observations, I used this access to make contact with white interns, build rapport, and recruit them into focus groups.

Must-hires are a well-kept secret. When the HR practitioners at my host agencies finally acquiesced and disclosed their must-hires to me, they did so behind closed doors and in hushed whispers, insisting I pretend that I did not know who they were, who they knew, and how they got in. Such caution is understandable, since identifying a must-hire would likely embarrass the powerful actors who used their influence to secure internship slots for family and friends. In order to protect my HR informants from possible reprisals from uppermanagement, I approached the must-hires at my host agencies from an oblique angle, inviting them to participate in my research by joining focus groups based on gender. Though this strategy of forming white/must-hire focus groups involved a degree of deception at the initial stage, it is common practice in social science to misdirect the participant and thereby mitigate the effect of social desirability. ${ }^{8} \mathrm{I}$ also gained informed consent from all of my participants by clearly identifying myself throughout as a researcher interested in issues of gender, race, class, and creativity in advertising. As an additional precaution, I sent a penultimate draft of my monograph to all 65 of my quoted participants and invited them to respond to my analysis. Of those, nine MAIP interns, seven white interns (four of whom were must-hires), and seven agency staff sent back comments. ${ }^{9}$ While one participant requested the removal of a potentially identifying piece of personal information, no one opted to withdraw from the study nor mentioned any concerns about my methods-whether when recruiting of participants, conducting focus groups, or reporting results.

In what follows, I analyze a set of on-site in-depth interviews with senior advertising practitioners along with off-site focus groups ${ }^{10}$ with interns from a wide range of agenciesboth white and of colour. ${ }^{11}$ My findings indicate that race in advertising is not only a problem of "the Other," namely minorities who have been marginalized and discriminated against, but also a problem of power granted through closed social networks then rendered invisible through the articulation of whiteness and class privilege (Dyer 1997). I argue that this consensus around meritocracy amongst interns signals a wider sense of colour-blindness in the advertising industry in general-namely the refusal to see a decidedly unequal playing field where cronyism eases the burden of entry for well-connected whites.

\footnotetext{
${ }^{7}$ All three of the agencies in my study have over 500 employees in their New York offices. Two are headquartered there. Two have international reach, with offices abroad. As a condition of access, I have granted the agencies anonymity and so will not name them here.

${ }^{8}$ Just as most quantitative surveys include dummy questions unrelated to the researchers' interests in order to conceal the study's hypotheses, qualitative researchers often design interview schedules to begin with nonthreatening questions in order to put their subjects at ease (Lindlof and Taylor 2002). For instance, Sut Jhally and Justin Lewis (1992), when conducting focus groups for their landmark book Enlightened Racism, did not disclose their main interest in issues of race and class up-front. Instead, they showed their research subjects episodes of The Cosby Show then posed innocuous open-ended questions designed to encourage comfortable and freeflowing conversations.

${ }^{9}$ The feedback from my MAIP participants was uniformly positive. Most noted their agreement with my analysis and conclusions, and others went on to thank me for putting their experience into words and to express their hope that the work would be widely read and applied within the US advertising industry. The responses from my white must-hire participants were mixed. While one thanked me for not presenting the must-hires "as spoiled, privileged, obnoxious college students" and another said my analysis "truly gives me pause to rethink what I do on a daily basis," two others were more circumspect, wishing me luck while expressing disappointment about being labeled a must-hire, and thus undeserving, by my HR informants.

${ }^{10}$ I conducted my focus groups in neutral locations (such as NYU and the MAIP residence) outside the purview of the interns' agency supervisors so as to encourage them to speak freely about their experiences and opinions.

${ }^{11}$ I refer to all of my study participants using first name pseudonyms.
} 


\section{Production: Opportunity Hoarding}

Starting on the production side of Johnson's circuit, it is important to understand that advertising does not just produce promotional messages; it also reproduces white labour. One mechanism for this reproduction is the culture of "must-hires," a material practice that is endemic to advertising internship programs. Colloquially defined within agencies as interns hired because of who they know, they are also referred to as "must-takes," "favour-hires," and "asks." In practice, these "requests" function more like commands and tend to be honoured by HR since they either come from clients ("let's say the chairman of Proctor [\& Gamble] calls up and says, 'Hey, my kid, my niece, my God child"') or agency uppermanagement ("the CEO's assistant's step-daughter or so-and-so's best friend"). Of course, as we've seen in Deirdre Royster's (2003) work on "embededness," nepotism, and opportunity hoarding are nothing new. What makes this particular instance remarkable is how-even in the midst of a diversity crisis-the US advertising industry's must-hire system overwhelmingly favours whites. In the three agencies where I conducted ethnographic fieldwork, all of the must-hire interns were white and outnumbered the MAIP interns of colour 24 to nine, a ratio of more than $2: 1$.

In this section, I analyze a representative set of testimonials from each of my three host agencies that illuminate the must-hire system from a variety of white perspectives: Heather, an HR Manager, reluctantly acquiesces to her boss; Patricia, an HR Director, ponders doing a favour for a colleague; and James, a high-powered CMO, "pays it forward" to his alma mater, a co-worker, and even his own family. For Heather, who runs her agency's internship program and resents the must-hire system, "the nepotism factor is really, really tough. Like the lengths you need to go to say 'no' and the number of people who you cannot say 'no' to... What am I going to say? 'CEO, I don't like your pick?' Heather estimates that hundreds of students apply to her internship program every summer, but doesn't bother reading their materials since "to get in is word-of-mouth here with some sort of connection." Patricia, whose agency's internship program is similarly competitive, recounted her own struggle with nepotism when a white colleague asked her to consider hiring his son's friend: "and he goes, 'I'm not asking for a favour or anything' but you know what? I was torn.... So [after the interview] I said, 'Listen, he was okay, I probably wouldn't normally have passed him on, but, if you want me to pursue it, I'd be happ_-if that's what you want.... and I was all like 'Oh my God! This is how it happens!" Patricia would have made the hire if pressed. Ultimately, she didn't, but still granted her colleague a privileged form of access for his family friendreserved for him and denied to others by virtue of proximity, not qualification. And, while access alone may be an insufficient condition for getting into a highly desirable internship program at a major agency, as we learned from Heather, it is almost always a necessary one. James, a top executive at my third host agency, knows this all too well and took great pride in having helped various colleagues, friends, and family "get a foot in the door" of the industry-even managing to get his daughter's boyfriend's brother into his own agency's internship program. When I challenged this practice as nepotism, James was unrepentantarguing that the reciprocal exchange of favours "works two ways. It's a relationship bank system; you make withdrawals and deposits all the time." Thus, as a form of currency and reciprocal exchange among well-connected whites, must-hires constitute a system of noncompetitive, sole provider, and no-bid contracts. These inherently unequal opportunities are a prevalent, frequent, and expected form of white opportunity hoarding. As a structure of oppression, must-hires help to produce and maintain race inequality inside advertising. As a material practice of the everyday, depending on one's rank, must-hires can be an onerous obligation of employment or a pleasant ritual of "giving back," bestowing gifts, and/or making quid pro quo investments in the hopes of a future return-both personal and professional.

Despite vastly outnumbering interns of colour placed in agencies through programs like MAIP, must-hire interns seem to get a free pass from diversity advocates. When conducting my review of industry trade literature, I found plenty of opinion columns debating the relative 
importance of the diversity and various ways for agencies to achieve it, but none mentioning must-hires nor how they limit opportunity for people of color and perpetuate white privilege. This is remarkable-given the scarcity and desirability of internship slots as opportunities for access, training, and networking within a highly competitive industry-yet also understandable. Beyond the obvious disincentive against criticizing upper-management or resisting requests from clients, this silence, as we shall see, is further reinforced by a polarized debate over tactics pitting diversity activists against reformers.

\section{Texts: Diversity as "Smart" vs. "Right"}

In this section, I depart from the clandestine labour practice of must-hires, ensconced well within the production side of Johnson's circuit, and move out into the textual moment to consider a public debate vying to establish the discursive rationale for rectifying racial inequalities within advertising. This contest over meaning has taken place largely outside agency walls through, on the one hand, the reformist agenda of high-profile industrysponsored awards galas celebrating "rising stars" of colour and making the positive business case for diversity as "smart" given the rise of multicultural markets, and, on the other, the activist strategy of class action lawsuits and strident columns in trade magazines positioning diversity as simply the "right thing to do" in the face of injustice given the industry's longstanding and persistent resistance to hiring and promoting black employees (Parekh 2009). I interviewed several black human resource practitioners who complained that their attempts to reform the race crisis from within have been hindered by other blacks attacking the industry from without. For instance, when Omnicom, the second largest advertising holding company in the world, appointed Tiffany Warren, former director of the MAIP program, to the newly created position of Chief Diversity Officer, Sanford Moore, a pioneering black advertising practitioner and long-time civil rights activist, quickly dismissed her as a "sell out," "apologist," and "Uncle Tom" working for the owners of "the plantation" (Parekh 2009). For Moore (2009), the hiring of Warren was far too little and way too late:

We have had 40 years of pious pronouncements by the leaders of the industry, 40 years of investigations, reports and obfuscation, 40 years of denying the significance of the black consumer market. It is time to return the favor. It is time to make the CEOs of the holding companies pay a price with their own money, to affect their compensation packages and their company's stock price.

Dorothy, a senior-level woman of colour who has run internal diversity initiatives and aligns herself with Warren, worried that Moore's inflammatory rhetoric and confrontational activist tactics would backfire and undermine her more pragmatic, reformist approach. In separate interviews, many of her colleagues agreed that instead of threatening to punish the industry through penalties, Moore and his allies should emphasize diversity's potential rewards.

I heard the reformist business case for diversity early and often during my fieldwork. On the second day of MAIP's 2010 summer orientation, I joined about 40 interns in a conference room at 4A's headquarters in New York City as Executive Vice President Michael Donahue explained that, while diversity has "always been the right thing to do, now it's the smart thing to do," since multicultural people will represent half the population in the US by 2050 . This is not a new idea. Wally Snyder, president and CEO of the American Advertising Federation (AAF) argued back in 1993 that the increase of multicultural populations meant that a diversified workplace was "no longer simply a moral choice; it is a business imperative" (quoted in Kern-Foxworth 1994, 119). Donahue and Snyder's common claim underpins the central rationale of reformist discourse: structural adjustments or external regulations are no longer necessary because what was once a matter of conscience is now a necessity of capitalism: consumer demand will succeed where public activism and government intervention have failed. 
And yet, if hiring more black employees is "smart," then most agencies are still pretty dumb. The assumption that the market-on its own-will increase diversity within advertising is a dubious one, especially given Wieden's (2009) confession, cited above, that he has long enjoyed great success hiring whites to sell black culture to black consumers-a market Moore (2009) estimates to be worth just under $\$ 1$ trillion per year. Simply put, race inequality inside mainstream advertising agencies has thus far endured the kinds of financially incentivized reforms that the "emergence" of black buying power might have wrought. So, in the midst of this glaring contradiction between the professed valuation of diverse perspectives and the actual paucity of diverse employees within the advertising industry, and despite years of pressure from activists and government regulators to do the "right" thing, the internal reformist common sense still boils down to this: if we place more interns of colour into the pipeline, the free market will do the rest. The "smart" thing will bring about the "right" thing. Add colour, then stir. But what if the problem is not just too little diversity, but also too much whiteness? Not simply discrimination against people of colour, but also preference for must-hires? These questions are rarely asked because the insider vs. outsider positions personified by Warren and Moore mutually reinforce each other, creating an entrenched polemic that reduces the advertising industry's race crisis to a question of tactics for increasing "the numbers" of minority employees. By continuing to rehash debates over the relative effectiveness of threats vs. promises, penalties vs. rewards, diversity advocateswhether reformist or activist-have kept their eyes focused on the money and their backs turned to the door where whites (whether qualified or not) are free to come and go as they please.

\section{Readings: Colour-blind Racism as Meritocracy in Theory}

Thus far we have considered how whites consolidate economic power through closed social networks at the point of production and how the contested discourses of diversity activists and reformists produce texts that let them get away with it. I now turn to the readings of the interns themselves. Following Johnson's call to consider the more subjective side of social forms, or the way in which subjects interpret and understand their own material conditions, this section examines ideology and how common sense notions of meritocracy can blind us to the material practices of (white) racial preference.

I hosted six white focus groups in a seminar room at NYU. The interns came from three different agencies, so many were meeting each other for the first time. Some were musthires. Some were not. All were white. Throughout the sessions, the combination of latent class formations and manifest racial identities produced some surprising moments of mutual recognition. In one instance, John actually bragged about his relationship with his agency's Chief Operating Officer than called out Richard, who he had just met, by knowingly asking him, "So, how did you get your internship?" Richard reluctantly admitted that his uncle was the CEO of his agency. He hadn't told any of his peers but, if asked, claimed he would have said he applied, but then quickly added, "they're not going to deny the chairman's nephew." In a later interview, Richard's HR manager was blunt: "Why not let him in? He does know the right person." While this may sound rather matter-of-fact, Richard knew better than to admit it in public for this would risk exposing him to the kinds of stigma so often experienced by interns of colour.

While the white must-hires slipped past scrutiny, interns of colour-whether they were in the MAIP program or not-were easily spotted by non-must-hire whites as undeserving intruders. Gregory, a white non-must-hire, complained that MAIP hurt his chances by advantaging unqualified interns of colour: "Many MAIP kids are not ad majors or don't know the basics [...] they don't interview you, they're probably not even asked why they want to do advertising. It just seems unfair that people who have the advertising background and want to intern at a big agency can't do it when people who don't have the background are able to." 
Not yet aware of the must-hire system, ${ }^{12}$ Gregory was frustrated by the apparent ease by which interns of colour secured their internships along with a 70 percent housing subsidy. But while he might have expected commiseration from the three other whites in his focus group, what he got instead was a series of sheepish looks and awkward admissions; all three were must-hires who, prior to the internship, knew next to nothing about the industry. Thus, a critique aimed at interns of colour, the scapegoated others not in the room, landed instead on the Gregory's true rivals, sitting right across the table: unqualified, yet well-connected whites. In this case, whiteness created an ideological screen of pseudo-solidarity, blinding Gregory to the material barriers-both invisible and silent-of class privilege that separated him from the rest of the group. This kind of backlash against MAIP was common amongst all the white interns in my study. Even the must-hires, ${ }^{13}$ despite their own advantage, tended to oppose MAIP based on what Bonilla-Silva (2010) describes as the meritocratic principles of abstract liberalism: "Why should we use discrimination to combat discrimination? Two wrongs don't make a right. We should judge people by their merits and let the best person get the job or promotion" (262-63).

While whites used meritocracy to attack diversity programs, it also provided a defense for MAIP interns who were well aware of white resentment. During my focus groups with interns of colour, ${ }^{14}$ many emphasized the rigour (three rounds of elimination) of the MAIP application process: "There are no slackers in MAIP. You can't!" "I know everybody else earned this like I did." "I really feel like I earned my place here." Michele, who is Asian, was even more explicit, emphasizing the superiority of MAIP interns vis-a-vis must-hires: "every single person in MAIP is extremely qualified and has more experience and skill than many of the interns who got these internships just through connections." Amelia, who is black, was directly confronted by a must-hire and used meritocracy to fight back:

One intern guy, his brother works there and he was like "Oh, well some of us had to interview with HR" and then he turned to me and said, "Oh, no Amelia, we all know why you're here. We all know why you got in." And I let him know what it took for me to get here. Like the process that I had to go through-writing those essays, getting those letters of recommendation, those interviews-that's much more than you talking to your brother!

For Amelia, then, meritocracy offers her a defense against whites who might presume that her skin marks her as undeserving, even as they deny their own privilege in a system that already advantages them. So, while affirmative action may indeed be a necessary institutional corrective, it can mark and thereby further stigmatize individuals of color (already marked as minorities) who wish to be read by others as autonomous subjects who have earned their position through the merits of the free labour market. Given this context, it is unsurprising that most of the MAIP interns in my study opposed the idea of affirmative action, even as they took material advantage of the exclusive quotas set aside for interns of colour. Ideology is at its most powerful when it offers a simple explanation to reconcile-and thereby resolve-a complicated set of contradictions. Meritocracy, so deeply rooted in the American

\footnotetext{
${ }^{12}$ After reading a draft of this study, Gregory shared an interesting anecdote that illustrates how the domination of the must-hire system can pit working class whites against people of colour: "The non-must hires are left out to dry, we don't have the financial resources and connections of must-hires to get the opportunities nor are we eligible for the helping hand of MAIP or other affirmative action programs. Last summer my good friend, also an ad student from my school, applied and got an internship at an agency in Minneapolis. Turns out her and the one MAIP intern were the only two non must-hires who got into the program. There were 12 total interns. One MAIP, one out-of-state (my friend), and 10 must-hires. The MAIP intern was put up in an expensive, fully stocked apartment for the summer and my friend lived in the bad part of town where she could make rent with her $\$ 10 / \mathrm{hr}$ intern salary. All of the must-hires stayed with family."

${ }^{13}$ Of the thirteen white must-hires participating in my study, the majority (8/13 or 62 percent) were opposed to affirmative action while two had mixed feelings and four supported it.

${ }^{14}$ For a more developed analysis of my focus groups with black interns participating in the MAIP program, please see Boulton forthcoming.
} 
Dream's promise of upward mobility, offers the interns in my study_both white and of colour - a soothing ideological overlay that mutes the harsh material reality of unfair hiring practices in the US advertising industry.

\section{Conclusion: Seeing Whiteness}

During my interview with Elizabeth, a white Head of HR, I proposed that the must-hire system functioned as "affirmative action for whites". At first, she was defensive, "Well, they weren't all white!" But when I asked for a counter-example, she hesitated, then backtracked, conceding my point. Elizabeth's reaction suggests that, despite her awareness of the musthire system, she had never thought of it in racial terms. Similarly, while the extant critical work on internships has offered nuanced explanations of how un(der)paid internships can exploit the labour of vulnerable workers aspiring to achieve creative employment while reproducing the class advantages of the populations with enough family connections and financial subsidies to access desired opportunities and advance beyond the entry level, more work is needed on how these economic pressures intersect with, and reinforce, inequalities of race and ethnicity within the media industries (Hesmondhalgh and Saha 2013). Thus, if communication theory is to continue to develop beyond textual representation and audience reception in order to address labour at the point of production, then my research suggests that a "circuit of culture" approach might offer a way forward that accounts for subjectivities both within and around the workplace. Indeed, further research is needed on the "lived cultures" side of the circuit that further illuminates the context of racial and ethnic exclusion from the kinds of closed social networks that facilitate employment (Boulton forthcoming). Put another way, when a political economy structured in white racial dominance is obscured by ideologies of meritocracy signified both through discursive texts and subjective experiences, analysts must find new ways to detect, and then lift, the cloak of whiteness in ways that work to help liberate, and not further stigmatize or essentialize, people of colour. For example, even the most adamant critics of race inequality in the cultural industries should avoid presuming a necessary correspondence between opening more "pipelines" of diverse media workers and achieving better images of diverse populations as this assumption heaves onto people of colour an extra burden of representational responsibility from which whites are exempt.

I have argued that the debate between activists and reformers has framed the justification for more people of colour in advertising as either reparation for past discrimination or preparation for emerging markets. This framework not only overlooks the cronyism, nepotism, and white racial pattern of the must-hire system operative within the production side of the circuit, but also the readings and lived experiences of the MAIP interns of colour in my study who generally did not wish to be perceived as either affirmative action hires or spokespersons for, and thus limited to, their own race (Boulton forthcoming). In contrast, Johnson asks us to remember both the structural limits surrounding and agentive opportunities available to all social actors at every moment of the circuit. And if critical communication researchers wish to hasten the socially just organization of cultural production (Hesmondhalgh 2007), then it behooves us to ask just how our research, theoretical as it may be, will actually intervene into the lives of the most marginalized workers. The preceding analysis suggests that we might begin with a clear recognition of the class-inflected ways and means of white labour reproduction.

Must-hire interns gain unearned access to the advertising industry in secret under the cloak of whiteness. They are, in a sense, invisible: a few more familiar faces blending into a mostly white crowd. This blindness to whiteness makes whites hiring other whites on the basis of favours, "fit," and friendship hard to see (Boulton 2013). But imagine a black intern walking through the doors of a general market agency. She stands out; people that look like her are few and far between-especially at the top. Now compare this to a white intern. For him, the agency is like a fun house of mirrors, reflecting his own image from every direction. The possibilities are endless and the future looks bright. Perhaps he already knows 
someone: that friend in account services or his uncle in the C-suite. Perhaps they'll go to lunch. Perhaps not. Either way, if he's taken under their wing, it won't be seen as a race thing, even though it is.

\section{References}

4A's. 2010. MAIP. Accessed May 10, 2010. http://www2.aaaa.org/careers/internships/maip/Pages/default.aspx.

Acker, Joan. 2006. Inequality Regimes: Gender, Class, and Race in Organizations. Gender and Society 20 (4): 441-464.

Becker, Lee, Edmund Lauf, and Wilson Lowrey. 1999. Differential Employment Rates in the Journalism and Mass Communication Labor Force Based on Gender, Race, and Ethnicity: Exploring the Impact of Affirmative Action. Journalism \& Mass Communication Quarterly 76 (4): 631-645.

Bendick, Marc and Mary Lou Egan. 2009. Research Perspectives on Race and Employment in the Advertising Industry. Bendick and Egan Economic Consultants, Inc.

Bonilla-Silva, Eduardo. 2010. Racism Without Racists: Color-blind Racism and the Persistence of Racial Inequality in the United States. Lanham, MD: Rowman \& Littlefield.

Boulton, Christopher. 2013. The Ghosts of Mad Men. In The Routledge Companion to Advertising and Promotional Culture, edited by Matthew McAllister and Emily West, 252-266. New York: Routledge.

Boulton, Christopher. Forthcoming. Identities Inside Advertising: Race Inequality, Code Switching, and Stereotype Threat. Howard Journal of Communication.

Branch, Enobong H. 2011. Opportunity Denied: Limiting Black Women to Devalued Work. New Brunswick, NJ: Rutgers University Press.

Bristor, Julia M., Renee G. Lee and Michelle R. Hunt. 1995. Race and Ideology: African-American Images in Television Advertising. Journal of Public Policy \& Marketing 14 (1): 48-59.

Broyles, Sheri J., and Jean Grow. 2008. Creative Women in Advertising Agencies: Why So Few "Babes in Boyland?" Journal of Consumer Marketing 25 (1): 4-6.

Bureau of Labor Statistics. 2011. Labor Force Characteristics by Race and Ethnicity. Accessed December 15, 2012. http://www.bls.gov/cps/cpsrace2011.pdf.

Bush, Michael. 2011. Sorry State of Diversity in Advertising is also a Culture Problem. Accessed March 15, 2011. http://adage.com/article/news/lack-diversity-advertising-hiring/148565/

Carbado, Devon, and Mitu Gulati. 2003. The Law and Economics of Critical Race Theory. The Yale Law Journal 112: 1757-1828.

Chambers, Jason. 2008. Madison Avenue and the Color Line: African Americans in the Advertising Industry. Philadelphia, PA: University of Pennsylvania Press.

Cortese, Anthony J. P. 1999. Provocateur: Images of Women and Minorities in Advertising. Lanham, MD: Rowman \& Littlefield.

Cottle, Simon. 1998. Making Ethnic Minority Programmes inside the BBC: Professional Pragmatics and Cultural Containment. Media, Culture \& Society 20 (2): 295-317.

Das Gupta, Tania. 1996. Racism and Paid Work. Toronto: Garamond Press.

Dávila, Arlene M. 2001. Latinos, Inc.: The Marketing and Making of a People. Berkeley: University of California Press.

Dolliver, Mark. 2010. Creation of Super Bowl Spots a Whites-only affair. Accessed May 19, 2010. http://www.adweek.com/aw/content_display/news/agency/e3if2e371e23945e3cf8b21cd4a1a39662 2.

Downing, John and Charles Husband. 2005. Representing Race: Racisms, Ethnicity and the Media. London: Sage.

Drew, Emily. 2011. "Coming to Terms with our Own Racism": Journalists Grapple with the Racialization of Their News. Critical Studies in Media Communication 28 (4): 353-373.

Dyer, Richard. 1997. White. London: Routledge.

Edwards, Lee. 2013. Institutional Racism in Cultural Production: The Case of Public Relations. Popular Communication: The International Journal of Media and Culture 11: 242-256.

Fall Colors: Prime Time Diversity Report. 2003. Children Now.

Frenette, Alexandre. 2013. Making the Intern Economy: Role and Career Challenges of the Music Industry Intern. Work and Occupations 40 (4): 364-39. 
Gill, Rosalind. 2014. Unspeakable Inequalities: Post Feminism, Entrepreneurial Subjectivity, and the Repudiation of Sexism among Cultural Workers. Social Politics: International Studies in Gender, State \& Society 21 (4): 509-52.

Gilmore, Joelle S. and Amy Jordan. 2012. Burgers and Basketball: Race and Stereotypes in Food and Beverage Advertising Aimed at Children in the US. Journal of Children and Media (6) 2: 317-332.

Green, Venus. 2001. Race on the Line: Gender, Labor, and Technology in the Bell System, 18801980. Durham, NC: Duke University Press.

Gregory, Michelle R. 2009. Inside the Locker Room: Male Homosociability in the Advertising Industry. Gender, Work \& Organization 16 (3): 323-347.

Gross, Larry. 2001. The Paradoxical Politics of Media Representation. Critical Studies in Media Communication 18 (1): 114-119.

Henderson, Jennifer and Gerald Baldasty. 2003. Race, Advertising, and Prime-time Television. Howard Journal of Communications 14 (2): 97-112.

Hesmondhalgh, David. 2007. The Cultural Industries. 2nd ed. London: Sage.

Hesmondhalgh, David and Anamik Saha. 2013. Race, Ethnicity, and Cultural Production. Popular Communication: The International Journal of Media and Culture 11 (3): 179-195.

Hesmondhalgh, David and Sarah Baker. 2011. Creative Labour: Media Work in Three Cultural Industries. New York: Routledge.

Jhally, Sut and Justin Lewis. 1992. Enlightened Racism: The Cosby Show, Audiences, and the Myth of the American Dream. Boulder, CO: Westview Press.

Johnson, Richard. 1986. What is Cultural Studies Anyway? Social Text (16): 38-80.

Kern-Foxworth, Marliyn. 1994. Aunt Jemima, Uncle Ben, and Rastus: Blacks in Advertising, Yesterday, Today, and Tomorrow. Westport, CT: Greenwood Press.

Keuhn, Kathleen and Thomas F. Corrigan. 2013. Hope Labor: The Role of Employment Prospects in Online Social Production. The Political Economy of Communication 1 (1): 9-25.

Lapchick, Richard, Devan Dignan, Austin Moss II, Naomi Robinson, Brian Hoff, and Jamile Kitnurse. 2010. White Men Dominate Advertising Agencies' Creative Director Positions as Exemplified by Ads Aired During the Super Bowl. The Institute for Diversity and Ethics in Sport. Accessed May 15, 2010. http://www.madisonavenueproject.com/UserFiles/File/newMadisonAvenue2010.pdf.

Lindlof, Tom and Brian Taylor. 2002. Qualitative Communication Research Methods. 2nd ed. Thousand Oaks, CA: Sage Publications.

Logan, Nneka. 2011. The White Leader Prototype: A Critical Analysis of Race in Public Relations. Journal of Public Relations Research 23 (4): 442-457.

Mallia, Karen. 2009. Rare Birds: Why so Few Women Become Ad Agency Creative Directors. Advertising \& Society Review 10 (3). Accessed May 15, 2010. http://muse.jhu.edu/journals/advertising and_society_review/summary/v010/10.3.mallia.html.

Mazzarella, William. 2003. Shoveling Smoke: Advertising and Globalization in Contemporary India. Durham, NC: Duke University Press.

McGuire, Gail M. 2002. Gender, Race, and the Shadow Structure: A study of Informal Networks and Inequality in a Work Organization. Gender and Society 16 (3): 303-322.

Miller, Daniel. 1997. Capitalism: An Ethnographic Approach. Oxford: Berg.

Moeran, Brian. 1996. A Japanese Advertising Agency: An Anthropology of Media and Markets. Honolulu: University of Hawaii Press.

Monk-Turner, Elizabeth, Mary Heiserman, Crystle Johnson, Vanity Cotton, and Manny Jackson. 2010. The Portrayal of Racial Minorities on Prime Time Television: A Replication of the Mastro and Greenberg Study a Decade Later. Studies in Popular Culture 32 (2): 101-114.

Moore, Sanford. 2009. Apartheid Alive and Well on Madison Avenue. Accessed May 7, 2010. http://www.adweek.com/print/100220.

Neff, Gina. 2012. Venture Labor: Work and the Burden of Risk in Innovative Industries. Cambridge, MA: MIT Press.

Neff, Gina, Elizabeth Wissinger, and Sharon Zukin. 2005. Entrepreneurial Labor Among Cultural Producers: "Cool" Jobs in "Hot" Industries. Social Semiotics 15: 307-334.

Nixon, Sean. 2003. Advertising Cultures: Gender, Commerce, Creativity. London: Sage.

O'Barr, William M. 1994. Culture and the Ad: Exploring Otherness in the World of Advertising. Boulder, CO: Westview Press.

Oakley, Kate. 2011. In its Own Image: New Labour and the Cultural Workforce. Cultural Trends 20 (3/4): 281-289. 
Perlin, Ross. 2011. Intern Nation: How to Earn Nothing and Learn Little in the Brave New Economy. New York, NY: Verso.

Parekh, Rupal. 2009. For Diversity Officers, No Good Deed Goes Unpunished. Accessed May 21, 2010. http://adage.com/print?article_id=134418.

Royster, Deirdre. 2003. Race and the Invisible Hand: How White Networks Exclude Black Men From Blue-collar Jobs. Berkeley, CA: University of California Press.

Saha, Anamik. 2012. Beards, scarves, halal meat, terrorists, forced marriage": Television Industries and the Production of "Race". Media, Culture \& Society 34 (4): 424-438.

Seiter, Ellen. 1990. Different Children, Different Dreams: Racial Representation in Advertising. Journal of Communication Inquiry 14 (1): 31-47.

Sender, Katherine. 2004. Business, Not Politics: The Making of the Gay Market. New York: Columbia University Press.

Shome, Raka. 2000. Outing Whiteness. Critical Studies in Media Communication 17 (3): 366-371.

Signorielli, Nancy. 2009. Race and Sex in Prime Time: A Look at Occupations and Occupational Prestige. Mass Communication and Society 12 (3): 332-352.

Stahl, Matt. 2012. Unfree Masters: Recording Artists and the Politics of Work. Durham, NC: Duke University Press.

Streeter, Thomas. 2014. From Romanticism vs. Expertise to Romanticism as Expertise. Paper presented at the annual meeting for the International Communication Association, Seattle, Washington, May 22-24.

Turow, Joseph. 1997. Breaking Up America: Advertisers and the New Media World. Chicago: University Of Chicago Press.

Vallas, Stephen P. 2003. Rediscovering the Color Line Within Work Organizations: The "Knitting of Racial Groups" Revisited. Work and Occupations 30 (4): 379-400.

Watts, Eric K. and Mark P. Orbe. 2002. The Spectacular Consumption of "True" African American Culture: "Whassup" with the Budweiser Guys? Critical Studies in Media Communication 19 (1): 1-20.

Wieden, Dan. 2009. "What Old Men Think About When They Think About Getting Old." Speech presented at the 2009 4A's Leadership Conference, San Francisco, CA. Accessed May 7, 2010. http://www.aaaa.org/events/video/Pages/042909 wieden.aspx.

Wood, Doug. 2010. Book of Tens: Legal Predictions for 2011. Accessed March 15, 2011. http://adage.com/bookoftens2010/article?article id=147619.

\section{About the Author}

Christopher Boulton

Christopher Boulton is an Assistant Professor in the Department of Communication at the University of Tampa where he teaches critical media studies, television, and documentary. Before entering the academy, Boulton worked at Mister Rogers' Neighborhood, Travel Channel, CourtTV (now TruTV), and Discovery Channel. Boulton's research focuses on the intersection of communication, inequality, and activism, and his writing has been published in the International Journal of Communication, Advertising \& Society Review, The Routledge Companion to Advertising and Promotional Culture, and New Views on Pornography. 